\title{
Tertiary Anatomy and Physiology, A Barrier for Student Success
}

\author{
Julian Vitali ${ }^{1,2^{*}}$, Conner Blackmore ${ }^{1 *}$, Siavash Mortazavi $^{1} \&$ Ryan Anderton ${ }^{3,4}$ \\ ${ }^{1}$ School of Medicine, University of Notre Dame Australia, Fremantle, Western Australia, Australia \\ ${ }^{2}$ School of Medicine, University of Queensland, Brisbane, Queensland, Australia \\ ${ }^{3}$ School of Health Science and Institute for Health Research, University of Notre Dame Australia, Fremantle, \\ Western Australia, Australia \\ ${ }^{4}$ Perron Institute for Neurological and Translational Science, Nedlands, Western Australia, Australia \\ *Joint first authorship \\ Correspondence: Conner Blackmore, School of Medicine, University of Notre Dame Australia, Fremantle, Western \\ Australia, Australia
}

Received: January 13, 2020

Accepted: February 12, 2020

Online Published: February 27, 2020

doi:10.5430/ijhe.v9n2p289

URL: https://doi.org/10.5430/ijhe.v9n2p289

\begin{abstract}
Anatomy and physiology courses are a foundation for numerous degrees, but experience some of the highest failure rates of all undergraduate health science programs (Higgins-Opitz \& Tufts, 2014). While interventions have been developed in an attempt to remediate this concerning phenomenon, there is a paucity of evidence to determine the reason anatomy and physiology courses pose such an obstacle to students, and whether there are reliable early determinants for student success in these courses. This review will discuss why this obstacle exists, and the factors that contribute to success and failure in undergraduate anatomy and physiology courses.
\end{abstract}

Keywords: anatomy, physiology, health science, academic performance, barriers, success, failure

\section{Introduction}

The study of human anatomy requires significant intellectual effort to identify the diverse structures and their internal organisation, as well as comprehension of their relationships with other structures of the body (Pandey \& Zimitat, 2007). Likewise, physiology deals with the functions and activities of life (such as organs, tissues, or cells) including the physical and chemical phenomena involved (Gove, 1986). The notion that anatomy and physiology (A\&P) is an integral component of health science courses, is reinforced by the findings of Pandey \& Zimitat (2007) who discovered that many anatomists believe mastering the fundamental rote learning style of anatomy can aid students across numerous disciplines (Pandey \& Zimitat, 2007). This was further highlighted by Anderton and Chivers (2016) as well as Sitticharoon, Srisuma, Kanavitoon, and Summachiwakij (2014), who identified success in A \& P courses translates to, a remarkable overall university Grade Point Average (GPA) for both health science and medical student cohorts, respectively. Therefore, A\&P is an integral foundational subject, underpinning health and science undergraduate courses, and required for the advancement of allied health professionals.

Historically, anatomy has been taught within the first or second semester of undergraduate study, with such courses providing a base of knowledge required throughout the degree (Ramsden, 2003). Unfortunately, compressing such fundamental content into the early stages of a degree, where students fail to appreciate relevance, encourages superficial and inefficient learning (Ramsden, 2003). More so, in recent years an emerging trend has resulted in the downsizing of anatomy courses, likely a result of an expanding STEM (Science, Technology, Engineering, Mathematics) curriculum and a shortage of qualified anatomists to deliver course material (Bay \& Ling, 2007).

The majority of university health science courses, such as nursing, physiotherapy, radiology and medicine, require anatomy and physiology or other foundational biology subjects that include A\&P as core units (Gultice et al., 2015; Sefton, 2005). Therefore, in order to determine the factors that contribute to performance in anatomy and physiology, and improve student outcomes, one must first appreciate the perceived barriers and difficulties associated with learning these fundamental courses. 


\section{Factors that Contribute to Performance in Undergraduate Anatomy and Physiology}

The importance of A\&P as foundational content for health and science undergraduate courses presents a need to determine the elements leading to success in such courses (Harris et al., 2004). Fundamentally, these contributing factors can be defined as student's engagement in STEM throughout their schooling (Iowa Department of Education, 2013), and the environment and opportunity provided to students throughout secondary school.

\subsection{Gender Differences}

Findings from a number of studies illustrate a variety of fixed and modifiable variables have a significant and consistent impact on a student's performance ability in the first year of their tertiary studies (Andrew, 2018; Li \& Carroll, 2019; Mills et al., 2009; Tani, Dalzell, Ehambaranathan, Murugasu \& Steele, 2019). One of the most consistent and unmodifiable of these variables is gender, with females consistently outperforming their male counterparts academically in first year university courses (Win \& Miller, 2005). The suggestion that females consistently outperform males academically is strengthened by Pomerantz et al. (2002), which demonstrated this trend occurs from as early as elementary school, with females consistently outperforming boys academically in all four core subjects (language arts, social studies, science and mathematics). A similar trend was observed in tertiary health and science degrees, with superior performance of females compared to their male counterparts (Anderton \& Chivers, 2016; Davies et al., 2009), a phenomenon compounded by greater enrolment of females in life science degrees (Chee et al., 2005). A\&P are foundational first year subjects in tertiary health science degrees and therefore this relationship is transferable. Taken together the current state of the literature suggests some degree of gender effect, in favour of females, on performance in tertiary health science, and A\&P specifically.

The relationship between the female gender and higher academic performance has been investigated since the 1970's and is believed to be multifactorial encompassing the approach to feedback and achievement (Roberts, 1991), heightened desire to please peers (Pomerantz, Alterman \& Saxon, 2002), influence of social capital (Chee, Pino, \& Smith, 2005). and learning style (Nuzhat, Salem, Hamdan \& Ashour, 2013). There is a tendency for females to be more concerned with pleasing their peers, such as adults, parents and teachers, which may heighten their efforts to do well in school, thereby enhancing their academic performance (Pomerantz et al. 2001; Pomerantz et al. 2002). Another factor that is proving to underlie the gender differences in academic performance is the different approaches to achievement and feedback. Roberts (1991) argues that females view such situations as offering an opportunity to gain information about their ability and as a consequence view evaluative feedback as diagnostic. This approach may increase their effort to do well and thereby their academic performance because they view this performance as being informative about their abilities (Pomerantz et al. 2002). In addition, Chee et al. (2005) highlights the benefits of social relationships and social capital as a factor for increased academic performance by females as they are more likely to actively participate in student clubs and groups. Additionally, learning style preference is thought as an important determinant of academic performance (Nuzhat, Salem, Hamdan \& Ashour, 2013; Remali et al. 2013). As female students are identified as having diverse learning styles (Nuzhat, Salem, Hamdan \& Ashour, 2013; Remali et al. 2013), such multimodal learning which is associated with a higher cumulative GPA, could further explain the gender-associated differences.

\subsection{Secondary School Environment and Academic Performance}

In addition to school engagement in STEM programs, the respective schooling environment can significantly influences a student's future success in tertiary A\&P (Mills et al., 2009). An example of this was illustrated by Kumwenda et al. (2017) where students with equivalent entry scores for university courses found government schooled children consistently outperformed all other variables, inclusive of private and catholic schools when it came to summative tertiary results. However, this phenomenon was not recently established, with West (1985) finding students from independent schools were performing at the same level in tertiary education as those from government schools with matriculation scores one quarter to one half of a standard deviation beneath them.

Win and Miller (2005) sought to determine the effectiveness and contributing factors towards student's matriculation scores in Western Australia. As universities predominantly rely on matriculation scores for course selection, the factors that impact such scores are integral to education research. One of the key findings of their research was that schools attended have a significant impact on the academic performance of students once they have graduated and commenced tertiary education, students from government schools consistently outperformed students from catholic and independent schools at the university level (Win \& Miller, 2005).

High matriculation scores in STEM throughout schooling years provide one of the best predictive factors for success in tertiary A\&P (Mills et al., 2009). The relationship between such academic success and higher matriculations scores is 
well documented in educational research and thought to be the to a higher level of engagement, correlated with greater field interest and study effort (DeBerard, Spielmans, \& Julka, 2004; Murphy, Papanicolaou, \& McDowell, 2001). These links are not surprising when considering the impact that enhanced academic engagement has at various periods of one's educational journey. Moreover, increased engagement in the form of additional time spent on curriculum-based work; either in the household completing homework, or in the classroom, can be linked to higher achievements in school (Singh, 2010). Evans and Farley (1998); and Kumwenda et al. (2017) further demonstrated, through a study of students' academic results across multiple disciplines at university, that first year performance is related to students' prior academic achievements at secondary schooling, both overall and discipline specific. This trend extends to STEM, where students who have engaged well with STEM subjects throughout their high school years, achieve higher matriculation scores, and outperform those students who have not engaged with STEM prior to tertiary A\&P (Mills et al., 2009). The reason for such results was identified by Win and Miller (2005) as what is termed "inter school effects" such as the immersion effect and reinforcement effect, where students who are surrounded by other high achieving students begin to perform at an elevated level and continue to do so once at university respectively. This phenomenon is importantly separated from false perceived increased self-efficacy, where students who perceive themselves as high achievers without the academic skill set, seek less support and assistance from those around them, leading to the overall demise of academic results (Ofori \& Charlton, 2002). While engagement in STEM is linked to matriculation scores and further success in A\&P, this predictive factor is considered by some to be highly subjective as engagement can be a difficult variable to effectively measure (Wang, Bergin, \& Bergin, 2014). Therefore, it is important to assess student's overall performance as quantitative data sets, typically considered the next step in the sequence of increased engagement, as a predictor of success in tertiary A\&P (Anderton \& Chivers, 2016).

\subsection{Transition from Secondary School to University: The Impact on Tertiary A\&P Performance}

The transition from secondary school to university is particularly stressful, with success at university influenced by emotional and social competencies (Garg, Levin \& Tremblay, 2016; Parker, Saklofske \& Keefer, 2017; Parker, Summerfeldt, Hogan, \& Majeski, 2004). A significant number of secondary school students who commence tertiary educational institutes in Canada withdraw before graduation, across multiple discipline including health sciences. (Pancer, Hunsberger, Pratt, \& Alisat, 2000; Parker et al., 2004). High withdrawal rates are believed to be due to the variety of unique stressors faced by first year university students, which include making new relationships with peers, modifying existing relationships with friends and family, learning study habits in a new academic environment, as well as learning to function as independent adults (i.e. budgeting time and money) (Parker et al., 2004; Tinto, 1987).

Parker et al. (2004) identified a strong association between academic success in the form of a high (first year GPA) with dimensions of emotional intelligence (intrapersonal, adaptability, and stress management abilities), exclusively on young adults making the transition from high school to full-time study. The intrapersonal dimension involves the ability to distinguish among and label feelings, as well as the ability to use information about feelings to understand behaviour (Bar-On \& Parker, 2000; Parker et al., 2004). This suggests, that the ability to self-regulate emotions in the academic arena correlates with improved performance; that is - first year students who are able to adapt their learning, manage their new social stressors and identify their strength and weaknesses as they go, are able to perform better academically. The adaptability dimension specifically involves skills related to management, such as the ability to identify potential problems, as well as the use of realistic and flexible coping mechanisms (Bar-On \& Parker, 2000; Parker et al., 2004). The stress management dimension involves the ability to manage stressful situations in a relatively calm and proactive manner, where such people are rarely impulsive and work well under pressure (Bar-On \& Parker, 2000; Parker et al., 2004). However, it should be noted that an individual's emotional and social competencies will most likely change and adapt over the course of tertiary education, and that those who persevere are likely to have a different level of emotional intelligence following the completion of their degree (Parker et al., 2004).

Academic preparation and organisational skills have also been identified as factors that contribute to A\&P and overall academic success at university (Griff \& Matter, 2008; Gultice et al., 2015). Griff and Matter (2008) discovered a significant correlation between student's academic successes in a large A\&P course and when a personal electronic device,-which enabled participation in class quizzes, was registered. This finding demonstrated organisational skills as predictors of success in introductory A \& P course (Griff \& Matter, 2008).

Another factor affecting the transition from high school to tertiary education is the utilisation of an academic advisor for course selection exposure to college experience and help with balancing study, work and life issues (Gultice et al., 2015; Steele, 2018). Gultice et al. (2015) validated that a multifaceted approach between students and advisors regarding course selection could lead to appropriate remediation before a student registers for university, and when 
combined with targeted tutoring and support, a decrease in withdrawal and increased academic success. In the context of an undergraduate science study, faculty members and student advisors can guide underprepared students, such as those transitioning from high school to university, using supported pathways that help them to succeed in, enhancing the efficiency and effectiveness of faculty members (Brock, 2010; Frost, 1991; Gultice et al., 2015).

\section{Improving Performance in A\&P}

\subsection{Engagement in Secondary School}

Improving performance in tertiary A\&P begins well before the university classroom, with roots beginning in secondary school. While the magnitude of influence has been disputed, the contributing factors to success in tertiary education, regardless of stream, are undisputed. Success in tertiary A\&P requires enthusiasm and motivation (Hassan, 2008) and these are sentiments that are cultivated by a number of factors in the educational passage that include both subject selection and the schooling environment (Abbott-Chapman, Hughes, \& Wyld, 1992; DeBerard, Spielmans, \& Julka, 2004; Everett \& Robins, 1991; Mills et al., 2009). Therefore, it is reasonable to propose that an intervention that engages students in high school STEM and drives their subject choice to favour STEM may lead to enhanced student motivation and enthusiasm, manifesting as an overall improvement in A\&P performance in the tertiary setting.

Looking beyond engagement-based intervention programs, there is significant data to suggest gender environment may influence both STEM engagement and performance. Cherney \& Campbell (2011) illustrated that female single sex schooling is linked to the highest overall performance in STEM, with a higher achievement motive and self-esteem being established as a likely cause for increased performance. However, the improved academic performance did not correlate to overall interest in pursuing a future career in STEM. While single sex schooling was not responsible for increased career motivation, Solanki \& Xu (2018) established a significant effect of teacher gender on future profession interest. It was found that by having female STEM instructors, the gender gap was narrowed in terms of engagement. Not only did this lead to better academic performance, but both male and female students responded positively to female instructors with enhanced future interest in the field (Solanki \& Xu, 2018)

\subsection{How Modern A\&P is Taught: Delivery Matters}

The way in which A\&P content is delivered has remained constant in many institutions, with advancements in learning platforms providing opportunity for a more dynamic delivery. It is well supported in the literature that the incorporation of various active learning pedagogies into the teaching curriculum and faculty training has been demonstrated to support student learning (Freeman, Haak, \& Wenderoth, 2011; Gabriel, 2008; Roehl, Reddy \& Shannon, 2013; Simkins \& Maier, 2010). When the aforementioned pedagogies have been incorporated into biology courses, an increase in student A\&P performance was achieved (Gultice et al., 2015). This success was attributed to the focus on student engagement to learn by discussion and application, with the ability to provide instant feedback to assist in development and progress. As a continuation, Wilson, Taylor, Kowalski, and Carlson (2010) demonstrated the effective implementation of more inquiry-based content modules and increasing the number of "hands-on" activities to engage underprepared students. These aforementioned pedagogies increased the ease of explaining complex, abstract processes to students (Wilson et al., 2010), which is further supported by the similar findings of Hall \& McCurdy (1990) and Wood (2009).

Although, not directly linked to the delivery of A\&P, Gultice et al. (2015) demonstrated that a heavier course load in Anatomy and Physiology or Fundamentals of Biology correlated to the greater chance of student success in the course. This is not intuitive, as a heavier course load might be expected to negatively correlate with a student's academic performance, however these results are interpreted as a sign of commitment to the education process (Gultice et al., 2015). Student success secondary to greater course loads, is believed to be attributed to a student's increased focus on earning a degree, having to manage time more precisely, and the increased likelihood of engaging with the academic community (i.e. professors, other students or support services) (Astin, 1996; Gultice et al., 2015). Historically, class size has been indicated as a significant factor for student achievement, with smaller classes linked to an increase in student engagement, increased time on task, and the opportunity for high quality teachers to better tailor their instructions to the students in the class (Adunola, 2011; Blatchford, Goldstein, Martin, \& Browne, 2002; Freeman et al., 2014; Gultice et al., 2015; Pasternak, 2013; Schanzenbach, 2014). Additionally, in a recent report by Schanzenbach (2014) for the National Education Policy Centre, small class size (comprising an average of 15 students) was demonstrated to correlate with a positive impact on student engagement behaviours, which include higher levels of participation, initiative, and levels of effort put into class work. These student characteristics have

been highlighted as important in classroom learning and academic performance; and supported by earlier studies (Finn, 1997). Interestingly, and contrary to the argument regarding teacher experience and class size, positive 
impacts of small classes were found to be greater for more experienced teachers, as they were better able to take advantage of smaller class sizes to make pedagogical changes (Schanzenbach, 2006).

\section{Concluding Remarks}

Withdrawal and failure rates in gateway science courses, including anatomy and physiology, are some of the highest in developed higher education settings (Higgins-Opitz \& Tufts, 2014) and addressing this problem may require a multifaceted and versatile approach. Part of the reason for such high failure rates in introductory anatomy and physiology courses can be attributed to a continuing decline in the number of students entering university with higher-level STEM backgrounds. Thus, many students have been identified as requiring greater academic support in order to perform at the same level as their STEM established peers (Anderton \& Chivers, 2016; Mills et al., 2009). In addition to the paucity of foundational skills, age, emotional intelligence, teaching style, support systems and finances can affect an individual's success in anatomy and physiology (Griff \& Matter, 2008; Gultice et al., 2015; Parker et al., 2004). Therefore, this raised the important issue of how to combat and potentially support this cohort of students.

Participation in STEM subjects in secondary school, in addition to greater matriculation scores, provides one of the most accurate predictive factors for tertiary A\&P success to-date (Mills et al., 2009). The transition from high school to university is also a significant factor influencing performance in first year anatomy and physiology courses (Griff \& Matter, 2008; Gultice et al., 2015; Parker et al., 2004). While this transition may be perceived by students as being stressful, it encompasses unfamiliar intrinsic and extrinsic challenges. It would appear however, that those students who allow unfamiliarity to manifest continue to perform poorly, while those with emotional intelligence, intrapersonal, adaptability and stress management abilities adapt and succeed (Parker et al., 2004; Bar-On \& Parker, 2000). A final key element for student success in undergraduate A\&P is the delivery method of content, where various active learning pedagogies have been highlighted as factors for academic success.

Understanding the current state of tertiary A\&P, where schooling participation in STEM is continuing to decline coupled with rising failure rates, it is important to consider how one might alter the current pattern of behaviour. Future research should therefore aim to investigate interventions that enhance early STEM engagement or investigate the reason for a continuing decline in secondary school participation rates. By understanding the multitude and weighting of variables that contribute to student academic success in foundational science courses, inclusive of essential anatomy and physiology; we believe that institutions should focus on enriching undergraduate A\&P courses, rather than minimising classroom time and overloading curricula.

\section{References}

Abbott-Chapman, J., Hughes, P. W. \& Wyld, C. (1992). Monitoring student progress: A framework for improving student performance and reducing attrition in higher education.

Adunola, O. M. O. T. E. R. E. (2011). An analysis of the relationship between class size and academic performance of students. Nigeria: Ego Booster Books.

Anderton, R. \& Chivers, P. (2016). Predicting academic success of health science students for first year anatomy and physiology. International Journal of Higher Education, 5(1). https://doi.org/10.5430/ijhe.v5n1p250

Andrew, A. (2018). Factors Influencing Undergraduate Students' Academic Performance in Examination. International Journal of Research, e-ISSN, 2348-6848.

Astin, A. W. (1996). Involvement in learning revisited: Lessons we have learned. Journal of College Student Development, 37(2), 123-134.

Bar-On, R. E. \& Parker, J. D. (2000). The handbook of emotional intelligence: theory, development, assessment, and application at home, school, and in the workplace: Jossey-Bass.

Bay, B. H. \& Ling, E. A. (2007). Teaching of anatomy in the new millennium. Singapore medical journal, 48(3), 182.

Bilimoria, D. \& Lord, L. (2014). Women in STEM careers: International perspectives on increasing workforce participation, advancement and leadership: Edward Elgar Publishing.

Blatchford, P., Goldstein, H., Martin, C. \& Browne, W. (2002). A study of class size effects in English school reception year classes. British Educational Research Journal, 28(2), 169-185. https://doi.org/10.1080/01411920120122130

Brock, T. (2010). Young adults and higher education: Barriers and breakthroughs to success. The Future of Children, 109-132. https://doi.org/10.1353/foc.0.0040

Chee, K., Pino, N. \& Smith, W. (2005). Gender differences in the academic ethic and academic achievement. College Student Journal, 39(3), 604 - 618 
Cherney, I. D. \& Campbell, K. L. (2011). A league of their own: Do single-sex schools increase girls' participation in the physical sciences? Sex roles, 65(9-10), 712.https://doi.org/10.1007/s11199-011-0013-6

Dalziel, J. R. \& Peat, M. (1998). Academic performance during student transition to university studies. Paper presented at the R. Stokell (compiler), Proceedings of the Third Pacific Rim Conference on the First Year in Higher Education.

Davies, C., Heyworth, J., Rosenwax, L., Carr, S. \& Rosenberg, M. (2009). Factors associated with the academic success of first year Health Science students. Advances in Health Science Education, 14, 205-217. https://doi.org/10.1007/s10459-008-9103-9

DeBerard, M. S., Spielmans, G. I. \& Julka, D. L. (2004). Predictors of academic achievement and retention among college freshmen: A longitudinal study. College student journal, 38(1), 66-81.

Evans, M. \& Farley, A. (1998). Institutional characteristics and the relationship between students' first-year university and final-year secondary school academic performance: Monash University Australia.

Everett, J. E. \& Robins, J. (1991). Tertiary entrance predictors of first-year university performance. Australian Journal of Education, 35(1), 24-40. https://doi.org/10.1177/000494419103500105

Finn, J. D. (1997). Class Size: What Does Research Tell Us? Spotlight on Student Success.

Finn, J. D., Pannozzo, G. M. \& Achilles, C. M. (2003). The "why's" of class size: Student behavior in small classes. Review of Educational Research, 73(3), 321-368. https://doi.org/10.3102/00346543073003321

Fischer, F., Schult, J. \& Hell, B. (2013). Sex differences in secondary school success: Why female students perform better. European Journal of Psychology of Education, 28(2), 529-543. http://dx.doi.org/10.1007/s10212-012-0127-4

Freeman, S., Eddy, S. L., McDonough, M., Smith, M. K., Okoroafor, N., Jordt, H. \& Wenderoth, M. P. (2014). Active learning increases student performance in science, engineering, and mathematics. Proceedings of the National Academy of Sciences, 111(23), 8410-8415. https://doi.org/10.1073/pnas.1319030111

Freeman, S., Haak, D. \& Wenderoth, M. P. (2011). Increased course structure improves performance in introductory biology. CBE—Life Sciences Education, 10(2), 175-186. https://doi.org/10.1187/cbe.10-08-0105

Frost, S. H. (1991). Academic Advising for Student Success: A System of Shared Responsibility. ERIC Digest.

Gabriel, K. F. (2008). Teaching unprepared students: Strategies for promoting success and retention in higher education: Stylus Publishing, LLC.

Garg, R., Levin, E. \& Tremblay, L. (2016). Emotional intelligence: impact on post-secondary academic achievement. Social Psychology of Education, 19(3), 627-642. https://doi.org/10.1007/s11218-016-9338-x

Gove, P. B. (1986). New International Dictionary. Springfield, MA: Merriam-Webster Inc.

Gray, H. (1936). Anatomy of the human body (23d ed.). Philadelphia: Lea \& Febiger.

Griff, E. R. \& Matter, S. F. (2008). Early identification of at-risk students using a personal response system. British Journal of Educational Technology, 39(6), 1124-1130. https://doi.org/10.1111/j.1467-8535.2007.00806.x

Gultice, A., Witham, A. \& Kallmeyer, R. (2015). Are your students ready for anatomy and physiology? Developing tools to identify students at risk for failure. Advances in physiology education, 39(2), 108-115. https://doi.org/10.1152/advan.00112.2014

Hall, D. A. \& McCurdy, D. W. (1990). A comparison of a Biological Sciences Curriculum Study (BSCS) laboratory and a traditional laboratory on student achievement at two private liberal arts colleges. Journal of Research in Science Teaching. https://doi.org/10.1002/tea.3660270703

Harris, D. E., Hannum, L. \& Gupta, S. (2004). Contributing factors to student success in anatomy \& physiology: lower outside workload \& better preparation. The American Biology Teacher, 66(3), 168-175. https://doi.org/10.2307/4451650

Hassan, G. (2008). Attitudes toward science among Australian tertiary and secondary school students. Research in Science \& Technological Education, 26(2), 129-147. https://doi.org/10.1080/02635140802034762

Higgins-Opitz, S. \& Tufts, M. (2014). Performance of first-year health sciences students in a large, diverse, multidisciplinary, first-semester, physiology service module. Advances in Physiology Education, 38(2), 161-169. https://doi.org/10.1152/advan.00067.2013 
Hopper, M. (2011). Student enrolment in a supplement course for anatomy and physiology results in improved retention and success. Journal of College Science Teaching, 40(3), 70.

Iowa Department of Education (2013). Four Domains of Risk Factors. Iowa: Iowa Department of Education. Retrieved from https://educateiowa.gov/documents/learner-supports/2013/04/four-domains-risk-factor

Kumwenda, B., Cleland, J., Walker, K., Lee, A. \& Greatrix, R. (2017). The relationship between school type and academic performance at medical school: a national, multi-cohort study. BMJ Open, 7(8), e016291. https://doi.org/10.1136/bmjopen-2017-016291

Li, I. \& Carroll, D. (2019). Factors influencing dropout and academic performance: an Australian higher education equity perspective. Journal of Higher Education Policy And Management, 42(1), 14-30. https://doi.org/10.1080/1360080x.2019.1649993

Michael, J. (2006). Where's the evidence that active learning works? Advances in physiology education, 30(4), 159-167. https://doi.org/10.1152/advan.00053.2006

Michael, J. (2007). What makes physiology hard for students to learn? Results of a faculty survey. Advances in Physiology Education, 31(1), 34-40. https://doi.org/10.1152/advan.00057.2006

Mills, C., Heyworth, J., Rosenwax, L., Carr, S. \& Rosenberg, M. (2009). Factors associated with the academic success of first year health science students. Adv Health Sci Educ Theory Pract, 14(2), 205-217. https://doi.org/10.1007/s10459-008- 9103-9

Murphy, M., Papanicolaou, K. \& McDowell, R. (2001). Entrance score and performance: A three years study of success. Journal of Institutional Research, 10(2), 32-49.

Nuzhat, A., Salem, R., Hamdan, N. \& Ashour, N. (2013). Gender differences in learning styles and academic performance of medical students in Saudi Arabia. Medical teacher, 35, 78-82.

Ofori, R. \& Charlton, J. P. (2002). A path model of factors influencing the academic performance of nursing students. Journal of Advanced Nursing, 38(5), 507- 515. https://doi.org/10.1046/j.1365-2648.2002.02212.x

Pancer, S. M., Hunsberger, B., Pratt, M. W. \& Alisat, S. (2000). Cognitive complexity of expectations and adjustment to university in the first year. Journal of Adolescent Research, 15(1), 38-57. https://doi.org/10.1177/0743558400151003

Pandey, P. \& Zimitat, C. (2007). Medical students' learning of anatomy: memorisation, understanding and visualisation. Medical education, 4l(1), 7- 14. https://doi.org/10.1111/j.1365-2929.2006.02643.x

Parker, J. D., Saklofske, D. H. \& Keefer, K. V. (2017). Giftedness and academic success in college and university: Why emotional intelligence matters. Gifted Education International, 33(2), 183-194. https://doi.org/10.1177/0261429416668872

Parker, J. D., Summerfeldt, L. J., Hogan, M. J. \& Majeski, S. A. (2004). Emotional intelligence and academic success: Examining the transition from high school to university. Personality and individual differences, 36(1), 163-172. https://doi.org/10.1016/S0191-8869(03)00076-X

Pasternak, R. (2013). Discipline, learning skills and academic achievement. Journal of Arts and Education, 1(1), 1-11.

Pomerantz, E., Alterman, E. \& Saxon, J. (2002). Making the Grade but Feeling Distressed: Gender Differences in Academic Performance and Internal Distress. Journal of Educational Psychology, 94(2), 396-404. https://doi.org/10.1037/0022-0663.94.2.396

Pomerantz, E., Saxxon, J. \& Kenney, G. (2001). Self-evaluation: The development of sex differences. Cognitive social psychology: On the tenure and future of social cognition, 59-74. Mahwah, NJ: Erlbaum.

Ramsden, P. (2003). Learning to teach in higher education. Routledge. https://doi.org/10.4324/9780203507711

Remali, A. M., Ghazali, M. A., Kamaruddin, M. K. \& Kee, T. Y. (2013). Understanding academic performance based on demographic factors, motivation factors and learning styles. International Journal of Asian Social Science, 3(9), 1938-1951.

Roberts, T. (1991). Gender and the influence of evaluations on self-assessment in achievement settings. Psychological Bulletin, 109, 297-308. https://doi.org/10.1037/0033-2909.109.2.297 
Roehl, A., Reddy, S. \& Shannon, G. (2013). The Flipped Classroom: An Opportunity to Engage Millennial Students Through Active Learning Strategies. Journal of Family \& Consumer Sciences, 105(2), 44-49. https://doi.org/10.14307/jfcs105.2.12

Schanzenbach, D. W. (2006). What have researchers learned from Project STAR? Brookings papers on education policy, (9), 205-228. https://doi.org/10.1353/pep.2007.0007

Schanzenbach, D. W. (2014). Does class size matter? Retrieved from Colorado: Sefton, A. J. (2005). Charting a global future for education in physiology. Advances in physiology education, 29(4), 189-193. https://doi.org/10.1152/advan.00001.2005

Simkins, S. \& Maier, M. (2010). Just-in-time teaching: Across the disciplines, across the academy: Stylus Publishing, LLC.

Singh, K., Granville, M. \& Dika, S. (2002). Mathematics and science achievement: Effects of motivation, interest, and academic engagement. The Journal of Educational Research, 95(6), 323-332. https://doi.org/10.1080/00220670209596607

Sitticharoon, C., Srisuma, S., Kanavitoon, S. \& Summachiwakij, S. (2014). Exploratory study of factors related to educational scores of first preclinical year medical students. Advances in physiology education, 38(1), 25-33. https://doi.org/10.1152/advan.00162.2012

Smith, C. F. \& Mathias, H. S. (2010). Medical students' approaches to learning anatomy: students' experiences and relations to the learning environment. Clinical Anatomy: The Official Journal of the American Association of Clinical Anatomists and the British Association of Clinical Anatomists, 23(1), 106-114. https://doi.org/10.1002/ca.20900

Solanki, S. M. \& Xu, D. (2018). Looking Beyond Academic Performance: The Influence of Instructor Gender on Student Motivation in STEM Fields. American Educational Research Journal, 55(4), 801-835. https://doi.org/10.3102/0002831218759034

Steele, G. E. (2018). Student Success: Academic Advising, Student Learning Data, and Technology. New Directions for Higher Education, 2018(184), 59-68. https://doi.org/10.1002/he.20303

Tani, K., Dalzell, E., Ehambaranathan, N., Murugasu, S. \& Steele, A. (2019). Evaluation of factors affecting students' performance in tertiary education. Journal of Pedagogical Research, 3(2), 1-10. https://doi.org/10.33902/jpr.2019252504

Tay, R. S. (1994). Students' performance in economics: does the norm hold across cultural and institutional settings? The Journal of Economic Education, 25(4), 291-301.

Tinto, V. (1987). Leaving college: Rethinking the causes and cures of student attrition: ERIC.

Wang, Z., Bergin, C. \& Bergin, D. A. (2014). Measuring engagement in fourth to twelfth grade classrooms: The Classroom Engagement Inventory. School Psychology Quarterly, 29(4), 517. https://doi.org/10.1037/spq0000050

West, L. H. (1985). Differential prediction of first year university performance for students from different social backgrounds. Australian Journal of Education, 29(2), 175-187. https://doi.org/10.1177/000494418502900209

Wilson, C. D., Taylor, J. A., Kowalski, S. M. \& Carlson, J. (2010). The relative effects and equity of inquiry-based and commonplace science teaching on students' knowledge, reasoning, and argumentation. Journal of Research in Science Teaching: The Official Journal of the National Association for Research in Science Teaching, 47(3), 276301. https://doi.org/10.1002/tea.20329

Win, R. \& Miller, P. W. (2005). The effects of individual and school factors on university students' academic performance. Australian Economic Review, 38(1), 1-18. https://doi.org/10.1111/j.1467-8462.2005.00349.x

Wood, W. B. (2009). Innovations in teaching undergraduate biology and why we need them. Annual Review of Cell and Developmental, 25, 93-112. https://doi.org/10.1146/annurev.cellbio.24.110707.175306 